\title{
INCIDENCE OF SPINAL DEFORMITY IN ADULTS AND ITS DISTRIBUTION ACCORDING SRS-SCHWAB CLASSIFICATION
}

\author{
INCIDÊNCIA DA DEFORMIDADE VERTEBRAL NO ADULTO E SUA DISTRIBUIÇÃO \\ QUANTO À CLASSIFICAÇÃO SRS-SCHWAB
}

\section{INCIDENCIA DE LA DEFORMIDAD ESPINAL EN ADULTOS Y SU DISTRIBUCIÓN SEGÚN LA CLASIFICACIÓN SRS-SCHWAB}

Marcus Vinicius Amaral Barreto", Raphael de Rezende Pratali', Carlos Eduardo Gonçales Barsotti" ${ }^{1}$, Francisco Prado Eugenio dos Santos ${ }^{1}$, Carlos Eduardo Algaves Soares de Oliveira', Monica Paschoal Nogueira ${ }^{1}$

\begin{abstract}
Objective: To evaluate the incidence of spinal deformity in adults, as well as its distribution according the curve type and the occurrence of sagittal modifiers of the SRS-Schwab classification.. Methods: Radiographs in frontal and lateral views of the entire column were performed and radiographic parameters were used to diagnose the vertebral deformity for the classification according to the SRS-Schwab system. Results: We included 302 patients in the study, 236 (78.1\%) women and 66 (21.9\%) men. Fifty-six of the participants were diagnosed with ASD, 50 women and 6 men. The incidence of ASD was $18.5 \%$ in the total population, ranging from $9.1 \%$ in males and $21.2 \%$ in females ( $p=0.04$ ). As to age group, the incidence was $11.9 \%$ in patients between 18 and 39 years, $12 \%$ between 40 and 59 years and $28.8 \%$ in patients with 60 years of age or older, significantly higher in the oldest group $(p=0.002)$. When analyzing the correlation between age and progression of sagittal modifiers, there was no significant difference in the PI-LL and PT modifiers, but there was significant difference of SVA modifier ( $p=0.008$ ), with a higher age in individuals "++". Conclusion: This study presented demographic data on ASD in a Brazilian population sample. There was a higher incidence of ASD in females and individuals aged $\geq 60$ years. As for the sagittal modifiers of SRS-Schwab classification, there was a correlation between increasing age and degree of progression of SVA.
\end{abstract}

Keywords: Scoliosis; Aging; Incidence; Classification; Bone malignment.

\section{RESUMO}

Objetivo: Avaliar a incidência da deformidade vertebral do adulto, além de sua distribuição quanto aos tipos de curva e ocorrência de modificadores sagitais da classificação SRS-Schwab. Métodos: Trata-se de um estudo observacional prospectivo com pacientes adultos, com queixa relacionada com a coluna vertebral. Foram realizadas radiografias da coluna total de frente e de perfil e os parâmetros radiográficos foram utilizados para diagnosticar a deformidade vertebral para a classificação de acordo com o sistema SRS-Schwab. Resultados: Foram incluídos 302 pacientes no estudo, sendo 236 (78,1\%) mulheres e 66 (21,9\%) homens. Cinquenta e seis dos participantes foram diagnosticados com deformidade do adulto, seis homens e 50 mulheres. A incidência de deformidade do adulto foi de 18,5\% na população total, variando de 9,1\% no sexo masculino a 21,2\% no feminino ( $p=0,04)$. Quanto à faixa etária, a incidência foi de $11,9 \%$ nos pacientes entre 18 e 39 anos, $12 \%$ entre os de 40 e 59 anos e 28,8\% naqueles com $\geq 60$ anos, significativamente maior conforme aumento da idade $(p=0,002)$. Analisando a correlação entre idade e a progressão dos modificadores sagitais, não houve diferença significante quanto aos modificadores PI-LL e PT, porém houve diferença significante quanto ao modificador SVA ( $p=0,008)$, sendo maior a idade nos indivíduos "++". Conclusões: Apresentamos dados demográficos sobre a deformidade vertebral no adulto (DVA) em uma amostra populacional brasileira. Observa-se maior incidência da DVA no sexo feminino e em indivíduos com $\geq 60$ anos. Quanto aos modificadores sagitais da classificação SRS-Schwab, existe correlação entre o aumento da idade e a progressão do grau de SVA.

Descritores: Escoliose; Envelhecimento; Incidência; Classificação; Mau alinhamento ósseo.

\section{RESUMEN}

Objetivo: Evaluar la incidencia de la deformidad de la columna en adultos, así como su distribución en los tipos de curva y la aparición de modificadores sagitales de la clasificación SRS-Schwab. Métodos: Se realizó un estudio observacional prospectivo que incluyó pacientes adultos con quejas relacionadas con la columna vertebral. Se tomaron radiografías de toda la columna vertebral en vista frontal y perfil y se utilizaron parámetros radiográficos para diagnosticar la deformidad vertebral y para la clasificación según el sistema SRS-Schwab. Resultados: Se incluyeron 302 pacientes en el estudio, 236 (78,1\%) mujeres y 66 (21,9\%) hombres. Cincuenta y seis de los participantes fueron diagnosticados con DCA, 50 mujeres y 6 hombres. La incidencia de DCA fue de 18,5\% en la población total, variando desde 9,1\% en los hombres hasta 21,2\% en las mujeres $(p=0,04)$. En cuanto al grupo de edad, la incidencia fue del 11,9\% en pacientes entre 18 y 39 años, $12 \%$ entre 40 y 59 años y el $28,8 \%$ en pacientes con 60 años o mayores, significativamente más alta de acuerdo con el aumento la edad $(p=0,002)$. El análisis de la correlación entre la edad y la progresión de los modificadores sagitales no mostró diferencia significativa de los modificadores PI-LL y PT, pero hubo diferencia significativa en el modificador SVA ( $p=0,08)$, con una edad superior en los individuos " ++". Conclusiones: Se presentaron los datos demográficos sobre la DCA en una muestra de población brasileña. Hay una mayor incidencia de la DCA en mujeres y personas con 60 años o más. En cuanto a los modificadores sagitales de la clasificación SRS-Schwab, hubo correlación entre el aumento de la edad y el grado de progresión de la DCA.

Descriptores: Escoliosis; Envejecimiento; Incidencia; Clasificación; Desviación ósea.

1. The Orthopedic andTraumatology Service of Hospital do Servidor Público Estadual de São Paulo, São Paulo, SP, Brazil. 


\section{INTRODUCTION}

Adult spinal deformity (ASD) comprises a complex set of entities that include a wide range of clinical and radiographic characteristics, making it difficult to recognize and treat. ${ }^{1-6}$ Recent studies have shown a high prevalence, especially in the elderly population, reaching a rate of $68 \%$ in individuals over 60 years of age. ${ }^{7}$ Clinically, while some patients are asymptomatic, others complain of severe pain and functional disability that are often severe. Thus, the radiographic parameters should be considered when evaluating the quality of life. Several publications have shown a correlation between radiographic parameters of the spine and quality of life indicators. ${ }^{8-10}$

The treatment objectives and surgical strategies for ASD are entirely different from those of adolescent idiopathic scoliosis (AIS), and the classification systems used for this deformity are not useful for the deformity in adults. Due to the need for a comprehensive classification system for SD, the Scoliosis Research Society (SRS) has been working to produce one in recent years, with the evolution of several systems including clinical correlation parameters. ${ }^{11-13}$ In 2012, a new SD classification system presented, advocated by Schwab et al and called the SRS-Schwab Classification. This system (Figure 1) classifies the type of curve in the coronal plane, and includes three sagittal spinopelvic modifiers that reflect the components of the deformity in the sagittal plane, as well as the mechanisms used to compensate for the deformity. ${ }^{14}$ More recently, it was demonstrated that the SRS-Schwab classification system reflects the severity of the symptoms, in that both the type of curve and the sagittal modifiers have a significant correlation with quality of life indicators and the need for surgery. ${ }^{15}$

However, much of the information about ASD comes from other populations, and little data has been presented for Brazilian patients. Moreover, the classification system that is most widely accepted today - the SRS Schwab system - was developed and validated based on just a single population sample from the USA. The aim of our study was to present information about ASD in a Brazilian population sample, such as its incidence and distribution by age range and sex, as well as its distribution across the types of curves and the occurrence of sagittal modifiers within the SRS Schwab classification system. To date, there is no known data available on this subject.

\section{Types of curves}

\begin{tabular}{|ll|}
\hline $\mathrm{T}$ & $\begin{array}{l}\text { Thoracic } \\
\text { lumbar curve }<30^{\circ}\end{array}$ \\
$\mathrm{L}$ & $\begin{array}{l}\mathrm{TL} / \text { lumbar } \\
\text { thoracic curve }<30^{\circ}\end{array}$ \\
$\mathrm{D} \quad \begin{array}{l}\text { Double curve } \\
\text { T and T/L curve, both }>30^{\circ}\end{array}$ \\
$\mathrm{S} \quad \begin{array}{l}\text { Sagittal deformity } \\
\text { coronal curves }<30^{\circ} \mathrm{L} \\
\text { moderate or } \\
\text { severe modifier(s) }\end{array}$
\end{tabular}

T Thoracic

L TL / lumbar

thoracic curve $<30^{\circ}$

D Double curve

S Sagittal deformity

coronal curves $<30^{\circ} \mathrm{L}$

moderate or

severe modifier(s)

\section{Sagittal modifiers}

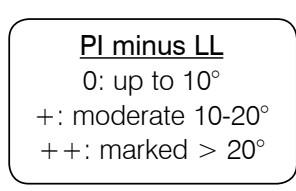

Global alignment

0 : SVA $<4 \mathrm{~cm}$

+ : SVA $4-9.5 \mathrm{~cm}$

$++:$ SVA $>9.5 \mathrm{~cm}$

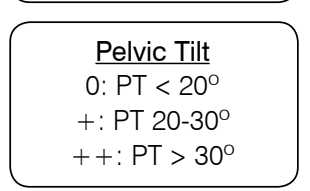

\section{METHODS}

This is a prospective, observational study involving adult individuals over the age of eighteen, who were seen at the same outpatient clinic, for complaints related to the spine. Following approval by the Ethics Committee, these individuals were invited to participate in the study, and radiographic images of the total spine (panoramic), scanned in front and profile views, were obtained, as well as demographic data, such as sex, age, weight, and height. Individuals who had undergone previous spinal surgery, or who had any neurological or neuromuscular pathology, or a history of traumatic lesion, spinal oncology, or the presence of any deforming disease of the lower limbs capable of affecting the individual's posture or the gait, were excluded from the study.

All the radiographs were obtained using a standardized technique, with the patients being asked to remain in a comfortable standing position, with the elbow in full flexion and the shoulder flexed at $45^{\circ}$, and with the hands relaxed and the fingers resting on the clavicle or the zygomatic bone. Individuals with exams of high technical quality allowing good visualization of the entire length of the spine, from C2 to the sacrum and to the head of the femur bilaterally, were considered suitable for the study.

The radiographic parameters of interest were evaluated using the Surgimap Spine software (Nemaris Inc. New York, USA) (Figure 2). Based on these radiographic parameters, ASD was diagnosed by the presence of at least one of the following criteria: deformity of the coronal plane with Cobb angle $\geq 20^{\circ}$; SVA $\geq 5 \mathrm{~cm}$; PT $\geq 25^{\circ}$, or thoracic kyphosis $\geq 60^{\circ}$.

The radiographic parameters were then used to classify those individuals diagnosed with ASD according to the SRS Schwab classification system. The demographic data considered were sex and age and the patients were divided into three groups by age range: Group 1 - from 18 to 39 years of age; Group 2 - from 50 to 59 years of age; and Group 3 - 60 years of age or older.

The incidence of ASD was compared across the different age groups using the Chi-square test. The correlation of the types of curve, and the progression of the sagittal modifiers of the SRS Schwab classification with the patients' age, was also analyzed, using the Analysis of Variance test (ANOVA), with a level of significance of $p<0.05$.

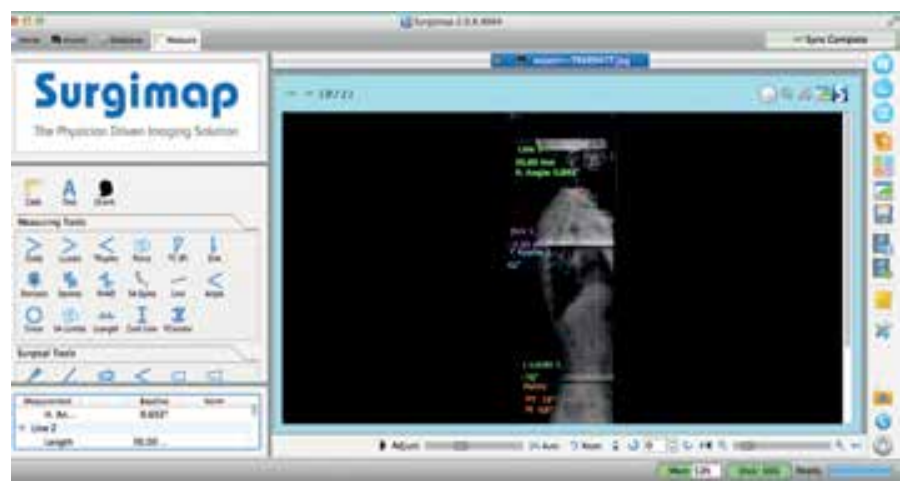

Figure 2. Illustration of the measurement of radiographic parameters using Surgimap Spine software (Nemaris Inc. New York, USA).

\section{RESULTS}

During the period from March 2013 to March 2014, 302 patients who met the inclusion criteria and signed the Informed Consent Form were included in the study. Of these, 236 were female (78.1\%) and 66 were male (21.9\%). The average age of the total study population was 52.7 years. An analysis of the radiographic parameters yielded 56 patients who met the criteria for a diagnosis of ASD, with an average age of 58.9 years; six men (10.7\%) and 50 women (89.3\%).
Figure 1. SRS-Schwab classification system, describing 4 types of curves and three sagittal modifiers. 
Thus, the incidence of ASD in the total study population was $18 \%$, ranging from $9.1 \%$ in the men to $21.2 \%$ in the women (Table 1), i.e. significantly higher in women $(p=0.04)$. As regards age range, the incidence of ASD was $11.9 \%$ in patients aged from 18 to 39 years, $12 \%$ in those aged from 40 to 59 years, and $28.8 \%$ in those aged 60 years or over. Comparing the incidence of ASD in the different age ranges, we observed a significantly higher incidence in population aged 60 years or over $(p=0.002)$. (Table 2$)$

The patients diagnosed with ASD were classified according to the SRS Schwab classification system. In terms of the type of curve (Table 3), ten (17.9\%) had a Thoracic curve (Type T), twenty (35.7\%) had a Lumbar curve (Type L), three (5.4\%) had a Double curve (Type D), and twenty-three (41.1\%) did not have a curve in the coronal plane (Type N), but only a deformity in the sagittal plane. Table 4 shows the distribution of patients by the sagittal modifiers of the SRS Schwab classification.

Table 5 shows the correlation between the progression of the sagittal modifiers and age. We observed no significant difference in terms of age in the degrees of either the PI-LL $(p=0.498)$ or PT $(p=0.257)$ sagittal modifier. However, there was a significant difference in terms of age, and the degrees of the SVA modifier $(p=0.008)$, with the " ++ " individuals being older.

Table 1. Incidence of adult spinal deformity in the total study population, distributed by sex and age range.

\begin{tabular}{c|c|c|c|c|c|c}
\hline & Total & Female & Male & $\mathbf{1 8 - 3 9}$ & $\mathbf{4 0 - 5 9}$ & $\geq \mathbf{6 0}$ \\
\hline Sample & 302 & 236 & 66 & 67 & 117 & 118 \\
\hline Cases & 56 & 50 & 6 & 8 & 14 & 34 \\
\hline Incidence & $18 \%$ & $21.2 \%$ & $9.1 \%$ & $11.9 \%$ & $12 \%$ & $28.8 \%$ \\
\hline
\end{tabular}

Table 2. There is no significant difference $(p=1)$ between the incidence of deformity in patients in the 18-39 and 40-59 years of age ranges. However, there is a significant difference $(p=0.02)$ between patients 60 years of age or older and the other groups.

\begin{tabular}{|c|c|c|c|c|c|c|c|c|}
\hline & & & Age $r$ & ange & \multirow[b]{3}{*}{$\mathbf{N}$} & \multirow{2}{*}{\multicolumn{2}{|c|}{ Total }} & \multirow{3}{*}{$\begin{array}{l}\text { Chi-square } \\
\text { test (p) }\end{array}$} \\
\hline & \multicolumn{2}{|l|}{$18-39$} & \multicolumn{2}{|c|}{$40-59$} & & & & \\
\hline & $\mathbf{N}$ & $\%$ & $\mathbf{N}$ & $\%$ & & $\%$ & & \\
\hline \multirow{2}{*}{$\begin{array}{l}\text { Deformity } \\
\text { Group }\end{array}$} & Negatives & 59 & $88.1 \%$ & 103 & $88 \%$ & 162 & $88 \%$ & 1.000 \\
\hline & Positives & 8 & $11.9 \%$ & 14 & $12 \%$ & 22 & $12 \%$ & \\
\hline \multicolumn{2}{|c|}{ Total } & 67 & $100 \%$ & 117 & $100 \%$ & 184 & $100 \%$ & \\
\hline & & \multicolumn{4}{|c|}{ Age range } & \multirow{2}{*}{\multicolumn{2}{|c|}{ Total }} & Chi-square \\
\hline & \multicolumn{2}{|c|}{$40-59$} & \multicolumn{2}{|c|}{$\geq 60$} & & & & test (p) \\
\hline & $\mathbf{N}$ & $\%$ & $\mathbf{N}$ & $\%$ & $\mathbf{N}$ & $\%$ & & \\
\hline \multirow{2}{*}{$\begin{array}{l}\text { Deformity } \\
\text { Group }\end{array}$} & Negatives & 103 & $88 \%$ & 84 & $71.2 \%$ & 187 & $79.6 \%$ & $0.002^{*}$ \\
\hline & Positives & 14 & $12 \%$ & 34 & $28.8 \%$ & 48 & $20.4 \%$ & \\
\hline \multicolumn{2}{|c|}{ Total } & 117 & $100 \%$ & 118 & $100 \%$ & 235 & $100 \%$ & \\
\hline
\end{tabular}

Table 3. Distribution of patients diagnosed with ASD by the type of curve from the SRS-Schwab Classification.

\begin{tabular}{c|c|c}
\hline Type of curve & $\mathbf{N}$ & $\%$ \\
\hline$T$ & 10 & 17.9 \\
\hline L & 20 & 35.7 \\
\hline$D$ & 3 & 5.4 \\
\hline N & 23 & 41.1 \\
\hline Total & 56 & 100 \\
\hline
\end{tabular}

Table 4. Distribution of patients diagnosed with ASD by the sagittal modifiers from the SRS-Schwab Classification.

\begin{tabular}{c|c|c}
\hline Modifier & $\mathbf{N}$ & $\%$ \\
\hline PT & & \\
\hline 0 & 31 & 55.4 \\
\hline+ & 18 & 32.1 \\
\hline++ & 7 & 12.5 \\
\hline Total & 56 & 100 \\
\hline SVA & & \\
\hline 0 & 26 & 46.4 \\
\hline+ & 20 & 35.7 \\
\hline++ & 10 & 17.9 \\
\hline Total & 56 & 100 \\
\hline PI - LL & & \\
\hline 0 & 36 & 64.3 \\
\hline+ & 9 & 16.1 \\
\hline++ & 11 & 19.6 \\
\hline Total & 56 & 100 \\
\hline
\end{tabular}

Table 5. Correlation between age and the progression of the sagittal modifiers of the SRS-Schwab Classification. There was no correlation between age and the progression of the modifiers PI - LL and PT ( $p=0.498$ and 0.257 ), but there was a significant correlation between age and the progression of SVA $(p=0.008)$.

\begin{tabular}{|c|c|c|c|c|}
\hline & \multicolumn{4}{|c|}{ PI - LL } \\
\hline & 0 & + & ++ & Total \\
\hline Average age & 57.2 & 58.4 & 64.7 & 58.9 \\
\hline Mean & 62 & 62 & 67 & 63.5 \\
\hline Standard deviation & 20.1 & 14.8 & 15 & 18.4 \\
\hline$n$ & 36 & 9 & 11 & 56 \\
\hline \multirow[t]{3}{*}{ ANOVA (p) } & 0.498 & & & \\
\hline & \multicolumn{4}{|c|}{ PT } \\
\hline & 0 & + & ++ & Total \\
\hline Average age & 56.9 & 58 & 69.6 & 58.9 \\
\hline Mean & 62 & 56.5 & 73 & 63.5 \\
\hline Standard deviation & 19.8 & 15.2 & 18.2 & 18.4 \\
\hline $\mathrm{n}$ & 31 & 18 & 7 & 56 \\
\hline \multirow[t]{3}{*}{ ANOVA (p) } & 0.257 & & & \\
\hline & \multicolumn{4}{|c|}{ SVA } \\
\hline & 0 & + & ++ & Total \\
\hline Average age & 51.8 & 61.5 & 71.9 & 58.9 \\
\hline Mean & 61 & 61.5 & 78 & 63.5 \\
\hline Standard deviation & 19.1 & 14.6 & 16.1 & 18.4 \\
\hline$n$ & 26 & 20 & 10 & 56 \\
\hline ANOVA (p) & 0.008 & & & \\
\hline
\end{tabular}

\section{DISCUSSION}

There is a tendency towards the aging of the population in general, with a considerable increase in the elderly population, and consequently, an increase in the diseases associated with advancing age. It has been shown that the occurrence of ASD, and all the associated functional limitations, are correlated advancing age. ${ }^{7}$ In this study, we observed that the incidence of deformity was significantly higher in the more elderly patients, in the age range 60 years of age or over $(p=0.0002)$. However, while a recent study showed that more than $60 \%$ of elderly individuals had some degree of deformity, ${ }^{7}$ the actual incidence of ASD diagnosed in our sample was $28.8 \%$ in the 60 years of age or over group.

In our sample, most of the patients evaluated were female, 236 (78.1\%) vs. 66 (21.9\%), with a significantly higher incidence of ASD among the females, $21.2 \%$ vs. $9.1 \%(p=0.04)$. Other studies have 
reported a higher percentage of $A S D$ diagnosed in females, $7,8,15$ reaching as high as $84.1 \%$. Based on what we observed regarding the distribution of the types of curves, with a predominance of curves without deformity in the coronal plane, and of lumbar curves over thoracic or double curves, we do not believe that the prevalence of ASD in women is influenced by the greater incidence of AIS in women, as most of the curves resulting from AIS are either thoracic or double curves.

Although ASD has a complex range of clinical and radiographic presentations, the recently developed SRS Schwab classification system ${ }^{14}$ has been widely used globally, and its relevance has been demonstrated, both for clinical correlation and treatment indication. ${ }^{15}$ Comparing the results of that study with our findings, which are based on a Brazilian sample population, a difference in the distribution of individuals with ASD by type of curve can be seen. In the study by Terran et al, ${ }^{15}$ the largest number of deformities are classified as double curves (Type D, 31.3\%), followed by thoracolumbar/lumbar curves (Type L, 29.7\%), deformities exclusively in the sagittal plane (Type N, 16.8\%), and thoracic curves (Type T, 14.3\%). In the current sample, a marked predominance of Type $\mathrm{N}$ curves (41.1\%) was observed, followed by Type $L$ curves (35.7\%), and type T curves (17.9\%), with a minority of curves classified as Type D (5.4\%).

As regards the sagittal modifiers described by the SRS Schwab classification, this study presents the distribution of the three modifiers (PT, SVA, and PI-LL) by class $(0,+$, and ++$)$ across the Brazilian population sample. In our study, the analysis performed showed a progressive increase in age with the progression of the three sagittal modifiers. While this correlation was not significant for the PT and PI-LL modifiers ( $p=0.498$ and $p=0.257$ ), it was significant for SVA $(p=0.008)$. Recently, Fu et al published a study of patients with ASD who underwent surgery or conservative treatment and stratification by age range demonstrated a worsening of SVA as age increased, associated with a worsening of quality of life indicators. ${ }^{16}$

This aim of this study was not to analyze the correlation between the distribution of the patients in the sample, in terms of the types of curves and sagittal modifiers of the SRS Schwab classification, and the clinical parameters (quality of life indicators). However, a worsening of the classification level of the sagittal modifiers has been associated with a worsening of those clinical parameters, a higher occurrence of surgical treatment, and a greater need for complex surgeries involving osteotomies. ${ }^{15}$ Almost all the information about the study of ASD is based on other populations, and data from studies involving the Brazilian population samples is lacking. We intend to pursue this line of study in the future, evaluating additional information about the correlation of the SRS Schwab classification with clinical parameters and treatment indications in a Brazilian population sample, to demonstrate the relevance of this classification system for our context.

\section{CONCLUSIONS}

This study presents the demographic data about adult spinal deformity (ASD) in a Brazilian population sample. A higher incidence of ASD is observed among the females and in individuals sixty years of age or older, as compared to the other younger age ranges. Regarding the sagittal modifiers, there is evidence of a non-significant progression of the PT and IP-LL modifiers in accordance with increasing age, but a significant correlation exists between increased age and worsening degrees of SVA.

All authors declare no potential conflict of interest concerning this article.

\section{REFERENCES}

1. Aebi M. The adult scoliosis. Eur Spine J. 2005;14(10):925-48.

2. Bess S, Boachie-Adjei O, Burton D, Cunningham M, Shaffrey C, Shelokov A, et al. Pain and disability determine treatment modality for older patients with adult scoliosis, while deformity guides treatment for younger patients. Spine (Phila Pa 1976). 2009;34(20):2186-90.

3. Smith JS, Fu KM, Urban P, Shaffrey $\mathrm{Cl}$. Neurological symptoms and deficits in adults with scoliosis who present to a surgical clinic: incidence and association with the choice of operative versus nonoperative management. J Neurosurg Spine. 2008;9(4):326-31.

4. Smith JS, Shaffrey $\mathrm{Cl}$, Berven S, Glassman S, Hamill C, Horton W, et al. Operative versus nonoperative treatment of leg pain in adults with scoliosis: a retrospective review of a prospective multicenter database with two-year follow-up. Spine (Phila Pa 1976). 2009:34(16):1693-8

5. Smith JS, Shaffrey Cl, Berven S, Glassman S, Hamill C, Horton W, et al. Improvement of back pain with operative and nonoperative treatment in adults with scoliosis. Neurosurgery. 2009;65(1):86-93.

6. Smith JS, Shaffrey Cl, Glassman SD, Berven SH, Schwab FJ, Hamill CL, et al. Risk-benefit assessment of surgery for adult scoliosis: an analysis based on patient age. Spine (Phila Pa 1976). 2011;36(10):817-24.

7. Schwab F, Dubey A, Gamez L, El Fegoun AB, Hwang K, Pagala M, et al. Adult scoliosis: prevalence, SF-36, and nutritional parameters in an elderly volunteer population. Spine (Phila Pa 1976). 2005;30(9):1082-5.

8. Glassman SD, Bridwell K, Dimar JR, Horton W, Berven S, Schwab F. The impact of positive sagittal balance in adult spinal deformity. Spine (Phila Pa 1976). 2005;30(18):2024-9.

9. Lafage V, Schwab F, Patel A, Hawkinson N, Farcy JP. Pelvic tilt and truncal inclination: two key radiographic parameters in the setting of adults with spinal deformity. Spine (Phila Pa 1976). 2009:34(17):E599-606.

10. Schwab FJ, Blondel B, Bess S, Hostin R, Shaffrey Cl, Smith JS, et al. Radiographical spinopelvic parameters and disability in the setting of adult spinal deformity: a prospective multicenter analysis. Spine (Phila Pa 1976). 2013;38(13):E803-12.

11. Schwab F, Farcy JP, Bridwell K, Berven S, Glassman S, Harrast J, et al. A clinical impact classification of scoliosis in the adult. Spine (Phila Pa 1976). 2006;31(18):2109-14.

12. Schwab F, Lafage V, Farcy JP, Bridwell K, Glassman S, Ondra S, et al. Surgical rates and operative outcome analysis in thoracolumbar and lumbar major adult scoliosis: application of the new adult deformity classification. Spine (Phila Pa 1976). 2007;32(24):2723-30.

13. Schwab FJ, Lafage V, Farcy JP, Bridwell KH, Glassman S, Shainline MR. Predicting outcome and complications in the surgical treatment of adult scoliosis. Spine (Phila Pa 1976). 2008;33(20):2243-7

14. Schwab F, Ungar B, Blondel B, Buchowski J, Coe J, Deinlein D, et al. Scoliosis Research Society-Schwab adult spinal deformity classification: a validation study. Spine (Phila Pa 1976). 2012;37(12):1077-82.

15. Terran J, Schwab F, Shaffrey Cl, Smith JS, Devos P, Ames CP, et al. The SRS-Schwab adult spinal deformity classification: assessment and clinical correlations based on a prospective operative and nonoperative cohort. Neurosurgery. 2013;73(4):559-68.

16. Fu KM, Bess S, Shaffrey Cl, Smith JS, Lafage V, Schwab F, et al. Patients with adult spinal deformity treated operatively report greater baseline pain and disability than patients treated nonoperatively; however, deformities differ between age groups. Spine (Phila Pa 1976). 2014;39(17):1401-7. 